\title{
CHALLENGES FACING FEMALE MUSLIM MEDICAL PRACTITIONERS (FMMP) IN THE UNIVERSITY COLLEGE HOSPITAL (UCH), IBADAN, NIGERIA
}

\author{
Muritala Kewuyemi Kareem * \\ Jamilah Adenike Adeogun **
}

\begin{abstract}
In Nigeria, religious intolerance between Muslims and Christians continues to increase. Muslim women are among those who have felt the most impact from the resulting religious prejudice, intolerance, and discrimination, especially in their workplaces. While many studies have been conducted to investigate the myriads of challenges facing women in general and Muslim women in particular, little research has been done on the challenges they face in their workplaces. This study intends to fill this gap by studying Female Muslim Medical Practitioners (FMMP) at the University College Hospital (UCH), Ibadan, Nigeria. Purposive and snowball samplings were used to select seventy research participants. Face-to-face and in-depth individual interviews, which lasted between 30 minutes and three hours each, were used to collect data for the study, in which relevant statistical tests were used for data analysis. The study reveals that FMMPs in the hospital encounter several challenges, such as donning the hijab (the Muslim headscarf), performing daily prayers (salat), and employment opportunities. There is also evidence of high-level discrimination in the workplace. Finally, the study recommends that the management of $\mathrm{UCH}$ enhance its practice and policies regarding religious tolerance, equality, fairness, unity, and cooperation amongst its administrative staff and personnel.
\end{abstract}

Keywords: Hospitals, Religion, Discrimination, Female Muslim Medical Practitioners (FMMP), University College Hospital (UCH) Ibadan.

\section{Introduction}

Islamophobia and negative sentiments against Muslims have been a global issue. They include discrimination, intolerance, and prejudice. Religious intolerance in Nigeria, especially between Muslims and Christians, is rising daily and female medical practitioners are feeling its effects the most. Muslims who work in government-established institutions often experience a great test of faith and 
difficulty in practising Islam. Many Muslim women are also deprived of their fundamental human rights on the basis of their religion. The situation is worse in southwest and southeast Nigeria, where Christians dominate managerial positions in many government-owned and private institutions. Between the three major religious groups in Nigeria (i.e. Christians, Muslims, and adherents of traditional religions), the strongest political rivalry since the 1970s has been between the Christians and Muslims.

Nigeria's military healthcare facilities were mostly established after the First World War (1914-1918), which coincided with the amalgamation of its northern and southern protectorates. These government healthcare facilities were then converted into civilian hospitals. As healthcare management became more complex, their central administration was regionalised. In November 1952, the University College Hospital (UCH) in Ibadan was declared by the parliament as a public healthcare hospital that will manage most of the country's training of medical personnel and other healthcare professionals. The hospital now functions as a teaching and research hospital, in addition to its role as a general hospital.

The challenges facing Nigeria's Muslim women impedes their potential to live up to the standards set by Muslim women in the early days of Islam. Throughout the ages, Muslim women excelled in various areas, such as scholarship (Aishah, wife of the Prophet, specialised in Islamic jurisprudence and hadith), governance (Shajar al-Durr ruled Egypt in 1250), nursing (Rufayda al-Aslamiyyah was the first nurse in Islamic history, who treated the wounded in the wars that took place during the time of the Prophet), and mathematics (Lubna of Cordoba was a well-known mathematician in the $10^{\text {th }}$ century).

In regard to Muslim women in general, Sophia Ali found that most Muslim women employees are dissatisfied with their jobs because they were discriminated against in many career development opportunities. A. Wadud, in her book, also provided an account of Muslim women's workplace challenges, drawn from her personal experiences as a woman, wife, mother, and scholar of Islam. Wadud also explored an array of issues facing Muslim women, including social status, education, sexuality, and leadership.

Another issue for Muslim women in their workplaces is the hijab (headscraf). As a controversial article of clothing, the hijab is often identified as an obstacle that prevents women from contributing to the economy. This is despite the fact many Muslim women wearing the hijab have proven themselves to be successful entrepreneurs. In some countries, women who insisted on wearing the headscarf have been prevented from attending educational institutions or even jailed for violating the hijab ban. A study by A. Oba and Fatima Abubakar shows that the $h i j a b$ issue has been a source of religious friction in several countries, including 
in Nigeria. There are various works that document discrimination against the hijab in Germany, France, Scotland, and the United States. Nevertheless, little is known about the discrimination faced by FMMPs in the Nigerian healthcare sector. This study seeks to fill this gap by taking the UCH in Ibadan as a case study. In the end, this study recommends several policy decisions to reduce discrimination against FMMPs.

\section{Statement of the Problem}

It is generally observed that discrimination against women in workplaces starts from the recruitment stage. In addition to being a woman, discrimination against Muslim women is compounded by them belonging to an ethnic and religious minority. With the increase of women in the workforce, there is a need to examine if their religious status contributes to this discrimination and impedes their ability to carry out their duties. The following research questions were raised to guide the study: Are female Muslim medical practitioners (FMMPs) discriminated against due to their religious beliefs or mode of clothing? Can a FMMP avoid duties that go against her religious belief(s)? How often do FMMPs observe their salat at the assigned time while at work? Are FMMPs' jobs threatened due to their religious practices? These are the questions raised while studying FMMPs in the University College Hospital (UCH), Ibadan - the first teaching hospital in Nigeria.

\section{Research Objectives}

The purpose of this study is to assess the challenges facing female Muslim medical practitioners at the University College Hospital (UCH) in Ibadan. Other specific objectives of the study are to:

1. Examine the extent to which female Muslim medical practitioners are discriminated against due to their religious beliefs and mode of dress.

2. Ascertain if female Muslim medical practitioners can avoid duties that go against their religious beliefs.

3. Determine how often female Muslim medical practitioners observe their salah when at work.

4. Ascertain if female Muslim medical practitioners' jobs are threatened due to the practice of their religion. 


\section{Research Methodology}

Purposive and snowball sampling methods were used to select participant FMMPs from the University College Hospital, Ibadan, Oyo state. Questionnaires were distributed at several vantage points, such as praying rooms, wards, as well as the offices of consultants and resident doctors. The researcher also selected and contacted a selection of potential respondents and provided them with questionnaires. The respondents were then asked to help identify other participants they knew who could fill in the questionnaire or be interviewed. A total of 70 questionnaires were used for this study. The questionnaire was divided into three sections: Section A, consisting of 5 questions focusing on the sociodemographic background of respondents, and Sections B and C focusing on the challenges faced by female Muslim medical practitioners in the hospital. It is noteworthy to put on record that all respondents had tertiary education and were able to fill the questionnaire with minimal assistance.

Face-to-face and in-depth interviews were also used to collect data and supplement the questionnaires. Participants were informed that their participation was voluntary. Both structured and unstructured interviews were conducted, which gave participants the opport unity to freely express themselves about the challenges FMMPs face. The interviews lasted between 30 minutes and three hours. With the participants' permission, the interviews were audiorecorded. Participants' names are replaced here with pseudonyms, and the respondents had the benefit of being interviewed at their own convenience.

\section{Theoretical Framework}

Two theoretical frameworks, Social Identity Theory and Theory of Prejudice, were applied to analyse and explain the challenges faced by FMMPs in UCH. Muslims in general, and female Muslims, in particular, have been facing discrimination resulting from aversions to Islamic symbols (e.g. hijab) and practices (e.g. five daily prayers). Islamophobia and negative sentiments against Muslims are particularly evident in areas where Muslims are the minority. This phenomenon is not confined to developed countries but also manifests in developing countries such as Nigeria. Social Identity Theory was initially introduced by Tajfel (1978), and later by Tajfel and Turner (1979), and states that people can exhibit certain kinds of group behaviour such as in-group solidarity and being hostile to out-groups when forming a social identity. Turner et al. (1987) also emphasised that when a particular group grows more prominent, its features can strongly influence attitudes and behaviours. Consequently, 
differences in both inter- and intra-groups will be highlighted and given more emphasis. This theory, in a way, explains why FMMPs in UCH are discriminated against and why FMMPs who exhibit more Islamic symbols (such as hijab and prayers) are further discriminated against.

In a similar way, Theory of Prejudice also deals with the issue of group thinking and negative perception. Prejudice is the tendency of an individual or group of people to have negative thoughts and emotions towards other groups. It can also result in preconceived judgments about individuals based on their group membership. The out-groups (the prejudiced against people) are rejected and hated. For instance, those who have a prejudice against Muslims may believe that Muslims are dangerous, intolerant, etc. Prejudice can be approached in three ways. First is the personality-centred approach, which aims at locating the causes of prejudice from a personality dynamic perspective. People who are prejudiced see in others characteristics and feelings that they cannot accept. Those who are intolerant may not only deny their intolerance but also may accuse the prejudiced against people of intolerance. The second approach is the cultural-based approach. As the name indicates, this approach focuses on the effect of cultural norms and social situations. For instance, in certain social situations, the dominant group may deny minority groups resources in order to preserve their social interests. This approach also acknowledges the fact that prejudice may be passed from generation to generation. The last approach is based upon the power-conflict theory, which elaborates the dark inner workings of rationalising exploitation, racism, etc. This third approach, in a way, explains the dynamic of prejudice experienced by minority groups such as the FMMPs in $\mathrm{UCH}$, who are accused of being prejudicial by those who are prejudiced against them in the first place.

\section{Data Analysis and Discussion of Findings}

Data was generated from the field according to the research objectives stated earlier. The cumulative percentages of challenges facing Muslim female medical practitioners are represented in the figure below: 
Table 1: Challenges Faced by Female Muslim Practitioners (FMMPs) in UCH

\begin{tabular}{|l|l|l|l|}
\hline & Frequency & Percent & Cumulative Percent \\
\hline Discrimination by superiors & 21 & 30.0 & 30.0 \\
\cline { 2 - 4 } & 1 & 1.4 & 31.4 \\
\hline Doubtful competence & 1 & 1.4 & 32.9 \\
\hline Dress code & 24 & 34.3 & 67.1 \\
\hline Dress code and prayer & 1 & 1.4 & 68.6 \\
\hline $\begin{array}{l}\text { Enforcing Christian } \\
\text { holidays }\end{array}$ & 1 & 1.4 & 70.0 \\
\hline General Injustice & 1 & 1.4 & 71.4 \\
\hline Marginalisation & 1 & 1.4 & 72.9 \\
\hline $\begin{array}{l}\text { Mixing with the opposite } \\
\text { sex }\end{array}$ & 1 & 1.4 & 74.3 \\
\hline Nature of work schedule & 1 & & 77.1 \\
\hline No time for prayer & 1 & 1.4 & 80.0 \\
\hline Prayers at work & 7 & 1.4 & 97.1 \\
\hline Promotion, study leave & 1 & 10.0 & 98.6 \\
\hline Unable to practice Islam & 1 & 1.4 & 100.0 \\
\hline Total & 70 & 1.4 & \\
\hline
\end{tabular}

Table 1 provides an overview of some of the challenges facing FMMPs in UCH. The data shows that out of 70 respondents, 24 (34.3 percent) included dress code, especially the hijab, as one of the principle challenges FMMPs face in $\mathrm{UCH}$, followed by salat at 12.8 percent. During an interview with a reputable member of the Muslim community in the area who is also a doctor, the following statement emerged:

...[a] major issue is that our people do not complain; they are too afraid to complain. If given the opportunity by the Chief Medical Director (CMD) to state their grievances, they keep mute. They told the researcher about their problems because of the confidentiality clause and the fact that the researcher is also a female Muslim. ${ }^{1}$

He believes that people, especially Muslims, should be upfront and outspoken about their rights and needs in order to avoid being trampled down. This sentiment was also corroborated by another medical practitioner: 
I think, as Africans, we do not have the culture of making our grievances known. I tell people I am in academia, as a young man, a young medical student, a young resident doctor, and as a young lecturer, I was scared of what my 'superiors' can do to me. So, in our setting, our life is ruled by fear of what others can do to us. And as a minority group in $\mathrm{UCH}$, every Muslim medical practitioner is either afraid or too careful not to utter the wrong words. They don't have the courage to fight for their rights. ${ }^{2}$

\section{Minority Group}

Being the minority in the UCH community, FMMPs face quite a number of challenges. This includes the inability to form a formal union that would advocate their rights and privileges. The Christian community, as the majority, with a ratio of one-fourth of the population in every ward, has various associations within $\mathrm{UCH}$, with special access and privileges. Examples include the Catholic and Pentecostal associations. These Christian associations are allowed to come into the hospital wards for prayers, Bible study, evangelism, and sometimes even perform deliverance sessions. These privileges, however, are not extended to the Muslim community. Some nurses have also reported that they are facing many difficulties in getting sufficient workplace support from non-Muslims. This disadvantaged position deepens from time to time when there is news of terrorist actions by Muslim extremists in the North. During the interview session, a respondent gave an example of a period where text messages were sent throughout UCH labelling Muslims, both male and female, as dangerous. Muslims were then subjected to heavy scrutiny and suspicion; everyone walked around in fear of anyone wearing Muslim attire. The respondent also noted that the employment of Muslims during that year was reduced and hopeful FMMPs were told to remove their hijab in interview sessions with the management. Those who refused were not employed. ${ }^{3}$

Another respondent reported that:

When I started working at the University College Hospital, Ibadan, the number of Muslim nurses was nothing to write home about or be proud of, which was about 20 years ago. Many of my friends that attended the nursing school ended not applying for jobs in $\mathrm{UCH}$, due to the attitude associated with that place. And the Muslims that were already employed then could not do anything positive about it, so it was a position of either one deals with it or leave. ${ }^{4}$ 
The FMMPs in UCH have also explicitly complained about the generally low numbers of Muslim medical practitioners and the position Muslims find themselves in with the ethics committee, which consists of a Christian majority. An interview respondent said:

...look at the management of $\mathrm{UCH}$, and you can quickly identify the top echelon, the Chief Medical Director (CMD), Deputy Director of Finance, Head of Human Resources etc. Of all the people who constitute such positions, there is only one Muslim. ${ }^{5}$

However, there is an alternative opinion. In an interview with a male doctor about the relationship between being a minority and the inability to complain, he said:

... I do not think so; I think it is a larger thing. As Africans, as Nigerians, we do not complain generally. I think the system is cued in such a way that we are always depending on people's goodwill and so we do not want to lose this goodwill by complaining. In this instance, they (FMMPs) are afraid to report the wrong things done to them in order not to lose their jobs. ${ }^{6}$

\section{Dress Code and the Hijab}

The hijab, and Muslim dress code in general, promotes modesty and seeks to minimise vice and immorality in society. Islam sets the standards of decency for both men and women. The ideal Muslim male must always be covered in loose and unrevealing clothing from at least his navel to his knee. Allah the Exalted says in the Qur'an, Chapter al-Nur: 30-31:

Say to the believing men that they cast down their looks and guard their private parts; that is purer for them; surely Allah is Aware of what they do. And say to the believing women that they cast down their looks and protect their private parts (from illegal sexual acts) and do not display their ornaments except what appears thereof and let them wear their head-coverings over their bosoms... ${ }^{8}$

In $\mathrm{UCH}$, medical practitioners can be categorised into several groups, but most of those affiliated with this research were doctors and nurses. The dress code for doctors is quite simple and easy to recognise, female medical doctors 
wear corporate attire comprised of shirts and skirts, trousers, even gowns of different colours, and lab coats. The nurses, on the other hand, wear uniforms with designated colours matching their assigned wards. A respondent mentioned that certain superior officials have made it their daily business to pester her if any part of the hem of her hijab shows. The respondent also complained about the maximum length of skirts and shirts/blouses allowed, which is below the knee for skirts and only short-sleeved for blouses. When asked why they did not wear trousers instead, they responded that they prefer not to wear trousers out of fear of harassment.

\section{Table 2}

\begin{tabular}{|l|l|l|l|}
\hline \multicolumn{1}{|c|}{$\begin{array}{c}\text { Management discriminates } \\
\text { against the use of hijab }\end{array}$} & \multicolumn{1}{|c|}{ Frequency } & \multicolumn{1}{|c|}{$\begin{array}{c}\text { Percent } \\
\text { Percent }\end{array}$} \\
\hline Agree & 31 & 44.3 & 47.2 \\
\hline Undecided & 6 & 8.6 & 52.9 \\
\hline strongly disagree & 33 & 47.2 & 87.5 \\
\hline Total & 70 & 100.0 & 100.0 \\
\hline
\end{tabular}

The survey result provided in Table 2 (above) shows that 31 respondents (44.3 percent) believe that $\mathrm{UCH}$ discriminates against the use of hijab, while six (8.6 percent) are undecided. Thirty-three respondents ( 47.2 percent) do not believe that the management discriminates against female Muslims since they are officially allowed to don the hijab. Nevertheless, there are numerous cases where younger FMMPs have been harassed, but the matter was not brought up with upper management. According to a respondent:

...they have not been complaining. But whenever we hear or see such discriminations, we often take the necessary steps to correct it. Sometimes, it takes a third party to lodge a complaint for us. In my department, for example, a senior nurse tried to harass a younger nurse to remove her hijab, and a third person who heard them was the one to report the matter to me. But in a circumstance like that, if you are going to intervene, you have to be very careful because the person involved has not complained to you. So, I had to first approach the nurse and say 'I heard so and so'... when people complain, help is usually available, but most of the victims, for a certain reason, chose not to approach any of us in the first place. ${ }^{9}$ 
Table 3

\begin{tabular}{|l|l|l|}
\hline $\begin{array}{c}\text { FMMP will be queried if they } \\
\text { dress in an Islamic way }\end{array}$ & \multicolumn{1}{|c|}{ Frequency } & Percent \\
\hline Agree & 39 & 55.8 \\
\hline Undecided & 8 & 11.4 \\
\hline Disagree & 23 & 32.8 \\
\hline Total & 70 & 100.0 \\
\hline
\end{tabular}

Table 3 shows the frequency of FMMPs who are being queried if they dress in an Islamic way. Thirty-nine respondents ( 55.8 percent) agreed that they are being questioned by those around them, while 23(32.8 percent) disagreed. The belief that wearing the hijab attracts prejudice and discrimination has been a serious concern since it has been a reason for some FMMPs to leave Islam. ${ }^{10}$

\section{Table 4}

\begin{tabular}{|l|l|l|l|}
\hline $\begin{array}{c}\text { FMMP dress to suit } \\
\text { UCH dress code }\end{array}$ & Frequency & Percent & Cumulative Percent \\
\hline Agree & 50 & 70.6 & 91.3 \\
\hline Undecided & 5 & 7.1 & 35.5 \\
\hline Disagree & 15 & 21.4 & 32.1 \\
\hline Total & 70 & 100.0 & 100.0 \\
\hline
\end{tabular}

Additionally, this study also surveyed whether respondents believe that FMMPs are abiding with UCH's dress code. Table 4 shows that more than half (70.6 percent) of respondents believe that FMMPs indeed dress according to UCH's circular guidelines. However, five (7.1 percent) were undecided and fifteen (21.4 percent) disagreed. A possible reason behind this minority opinion might be negative personal experiences regarding hijab and external pressures. This was hinted at by an observation made by a male doctor, who said:

...wearing hijab is like a racist thing, like a situation of a black man in a white man's country. Everyone looks at you differently, like you are not supposed to be where you are. And when you look different, some people's duty is to make you feel inferior and make you look bad or like you are doing something wrong. ${ }^{11}$

This was corroborated by another practitioner, who said that FMMPs:

...rarely complain, for instance, we had a woman in the 'School of 
Nursing' who was harassed, I think, for wearing a scarf or a hijab. Even her husband came and said, "Look, this hijab thing, don't let it cause a problem, we do not want to lose our jobs since they said you should not wear it, do not wear it." So, she removed her hijab. That would not be my attitude; my attitude would be to say, "Look, it is your right, go fight it out."12

\section{Modesty in Call Rooms}

Muslim patients often express strong religious or cultural concerns about modesty, especially regarding treatment by someone of the opposite sex. A Muslim woman may need to cover her body completely and should always be given time and opportunity to do so before anyone enters her room. Women may also request that a family member be present during a checkup and that they keep their clothes on during a checkup whenever possible. Also, Muslim men may find examination by a woman to be extremely challenging. Nudity is emphatically discouraged. There should be no casual physical contact by nonfamily members of the opposite sex, such as shaking hands. Some Muslims may even avoid eye-contact as a function of modesty.

Respondents complained that call rooms are often congested and no separation or demarcation has been made. Male and female doctors, both Muslims and Christians, use the same call room. There is no privacy, and it has made praying in the call rooms, or even resting, very problematic. Performing salat is impossible due to the lack of space.

\section{Discrimination by Superior Officers}

This study also uncovers claims that UCH's superior officers have engaged in discrimination towards FMMPs. An example is given below:

I was queried because I went to the mosque to pray even though I did not have any patients that needed emergent medication; this has happened to me three times, and one of the officers warned me that I would be reported and she would write a letter of complaint against me despite leaving for less than fifteen minutes. ${ }^{13}$

More than one-third of respondents disagreed, however, that it was the $\mathrm{UCH}$ management that discriminates against Muslims. Instead, they felt 
the bulk of discrimination comes from the superior officers. However, many respondents agreed that the fault of the management is that they do not criticise those involved in committing discrimination. Due to power imbalances and an inability to do much, most FMMPs have developed the habit of ignoring unfavourable comments about either salat or the use of hijab.

\section{Table 6}

\begin{tabular}{|l|l|l|l|}
\hline $\begin{array}{l}\text { UCH discriminates } \\
\text { against FMMP }\end{array}$ & \multicolumn{1}{|c|}{ Frequency } & \multicolumn{1}{c|}{ Percent } & Cumulative Percent \\
\hline Agree & 24 & 34.3 & 34.3 \\
\hline Undecided & 17 & 24.3 & 58.6 \\
\hline Disagree & 29 & 41.4 & 94.3 \\
\hline Total & 70 & 100.0 & 100.0 \\
\hline
\end{tabular}

From the data analysis, 24 (34.3 percent) respondents agreed that the University College Hospital discriminates against Muslims; 17 respondents (24.3 percent) were undecided; while 29 (41.4 percent) disagreed. In this regard, a medical practitioner expressed the following:

...it is a very cautious matter. Because I am not a member of the management, even though I am the head of a small department in UCH. Second, perhaps more importantly, it is well known that Muslims are in the minority here and...when there are a majority and minority, there would always be efforts by both groups to dominate. Of course, it is easier for the one that is in the majority to prevail most of the time. We look at the management of $\mathrm{UCH}$, and you can quickly identify the top echelon, the Chief Medical Director (CMD), deputy director of finance, head of human resources etc. Of all of these people, there is only one Muslim, who is the director of administration. ${ }^{14}$

\section{Salat}

One of the most visible elements of Muslim worship is daily prayer. The literal definition of salat is prayer and supplication, while the technical religious definition of the term is "the act of devotion which begins with the takbiratulihram (the first uttering of Allahu Akbar) and ends with the taslim (the uttering of al-salam 'alaykum)." Due to the many restrictions on praying while at work, many respondents expressed their views on combining two prayers into one. A respondent reported that: 
...the treatment of the patients sometimes takes [such] a long time that two or more prayers have to be combined, even for jumu'ah..$^{15} \ldots$ We are allowed to perform jumu'ah at the central mosque if there is no emergency, but for other days, praying remains a contentious affair. ${ }^{16}$

Some of the FMMPs even had to miss most of the prescribed times for prayers. According to a respondent:

...so many times, I had to postpone my salat especially jumu'ah prayer, because I had to monitor the patients. We are the only two Muslim doctors in this wing and we are always on the same shift, especially on Fridays, so I had to stay, and my colleague would go and pray in the mosque. I observe my Dhuhr prayer on certain Fridays, and in other days at late hours when I get home. ${ }^{17}$

Other respondents also provided similar accounts, although with variations. For instance, there were several cases where superior officers intentionally assign FMMPs patients during prayer times. However, there were respondents who reported that sometimes their Christian friends help them monitor their patients while they observe their salat at the mosque.

\section{Table 7}

\begin{tabular}{|c|c|c|c|}
\hline $\begin{array}{l}\text { Is it convenient for } \\
\text { FMMPs to pray at } \\
\text { work? }\end{array}$ & Frequency & Percent & Cumulative Percent \\
\hline Yes & 7 & 10.0 & 10.0 \\
\hline No & 56 & 80.0 & 90.0 \\
\hline Others & 7 & 10.0 & 100.0 \\
\hline Total & 70 & 100.0 & \\
\hline $\begin{array}{l}\text { UCH management } \\
\text { allows FMMP to } \\
\text { pray on all days }\end{array}$ & Frequency & Percent & Cumulative Percent \\
\hline Agree & 12 & 17.2 & 21.4 \\
\hline Undecided & 2 & 2.9 & 20.0 \\
\hline Disagree & 56 & 80 & 64.3 \\
\hline Total & 70 & 100.0 & \\
\hline
\end{tabular}


In terms of working convenience, Table 7 shows that only 10 percent of respondents feel that it is convenient to pray at work, while 10 percent are neutral and 80 percent say it is not. Nevertheless, 12 respondents (17.2 percent) agreed that the management generally allows FMMPs to observe salat, while two (2.9 percent) were undecided and 56 ( 80 percent) disagreed. In relation to this matter, a respondent provides the following account:

....as nurses, we answer our superiors at work. But sometimes, their directives put us in a dilemma. Even when we are free when it is time to perform salat, they look for petty obligations that make us delay it. ${ }^{18}$

\section{Festivities in the Hospital}

The respondents also described how they are forced to celebrate Christian holidays at work and how relevant decorations are set up during those times. However, when it comes to eid-al-fitr, there are no similar efforts from UCH management. Nevertheless, a majority of FMMPs (77.1 percent) still reported that they enjoyed working at UCH because of its good facilities. Only some of the respondents reported that their only reason for remaining at $\mathrm{UCH}$ was to feed their families and that they would transfer away if given the opportunity to work at an Islamic hospital.

\section{Table 8}

\begin{tabular}{|c|c|c|}
\hline $\begin{array}{l}\text { Do you enjoy } \\
\text { working at UCH? }\end{array}$ & Frequency & Percent \\
\hline Yes & 54 & 77.1 \\
\hline No & 11 & 15.7 \\
\hline Others & 5 & 7.2 \\
\hline Total & 70 & 100 \\
\hline
\end{tabular}

\section{Female Muslim Medical Practitioners and Muslim Patients}

A male patient is considered fortunate if his request for a male physician is entertained. The standard procedure by $\mathrm{UCH}$ medical practitioners is to treat all patients the same and not differentiate between religions (e.g. Muslims or 
Christians). However, a medical practitioner said that in practice a patient's request for same-sex doctors or nurses is sometimes entertained unofficially, especially if the patient asked politely. ${ }^{19}$

\section{Table 9}

\begin{tabular}{|c|c|c|c|}
\hline $\begin{array}{l}\text { FMMP is excused } \\
\text { from attending } \\
\text { to patients of the } \\
\text { opposite sex }\end{array}$ & Frequency & Percent & Cumulative Percent \\
\hline Agree & 2 & 2.9 & 2.9 \\
\hline Undecided & 4 & 5.7 & 8.6 \\
\hline Disagree & 64 & 91.4 & 55.7 \\
\hline Total & 70 & 100.0 & 100.0 \\
\hline
\end{tabular}

Table 9 shows that only two respondents ( 2.9 percent) agreed that a FMMP is allowed to excuse themselves from attending patients of the opposite sex. Most practitioners, represented by 64 (91.4 percent), said that they are not allowed to switch patients, citing medical ethics (not abandoning a patient for another simply because of the patient's sex). ${ }^{20}$

\section{Employment Issues}

FMMPs in UCH spent a considerable amount of time expressing and describing what they have to go through in order to work at UCH. Some of the more detailed accounts are given below:

I was advised to remove my hijab before appearing for the interview if I wanted the job. This advice was given by others that had undergone the interview sessions. I knew that UCH was not hijab-friendly, but I had to try my luck. If it is to go by the appointment, there are not many Muslims in the UCH especially female medical practitioners; and some were converted to Christianity while in nursing school and could no longer change their names probably because of their certificates or other reasons. ${ }^{21}$

...the case of the hijab went to the extent of passport photographs. Any passport photograph taken with a hijab was rejected, and the person 
was told to take another. This is before the admission forms will be issued out. The barriers were just too much, and have discouraged many Muslim female medical practitioners from applying to the University College Hospital. Hijab cannot be worn in school premises. Muslims who are not committed to Islam would be converted to Christianity with ease. And UCH is neither a Christian hospital nor a Muslim hospital. It is for everybody. But because Christians are holding the management positions, they use the opportunity to marginalise Muslims. ${ }^{22}$

\section{Table 10}

\begin{tabular}{|c|c|c|}
\hline $\begin{array}{l}\text { Has any FMMP been } \\
\text { sacked for upholding } \\
\text { her religion over } \\
\text { work ethics? }\end{array}$ & Frequency & Percent \\
\hline Yes & 12 & 17.1 \\
\hline No & 46 & 65.7 \\
\hline Others & 12 & 13.2 \\
\hline Total & 70 & 100 \\
\hline
\end{tabular}

The data shown in Table 10 shows that 12 respondents (17.1 percent) agreed that $\mathrm{UCH}$ discriminates in the employment process on the basis of religion, while 46 (65.7 percent) disagreed. Despite the higher percentage of respondents saying that they disagreed, qualitative research shows that discrimination can sometimes occur before the employment process, and often leaves no tangible evidence (i.e. documents, reports) that can be referred to:

...employment, unfortunately, is a privilege, whether we like it or not. Yes, you have certificates, but you would be one of many who have what they are asking for. So, they would say they want to organize an interview and interview is totally subjective. For example, in the School of Nursing in a year, 1000 people applied, 40 percent were Muslims, and 60 percent were Christians, only 200 people passed out of 1000. Out of the 200, 180 were Christians, and the remaining 20 were Muslims. What happened? Are Muslims generally dull? Out of all who passed and were invited for an interview, 95 percent were Christians, and only five percent were Muslims. We can challenge them as a community and say look we want to see the raw scores, the exam scripts of all Muslim candidates, we want to see how they are marked 
compared to their other colleagues. We want to understand how only 2 percent of Muslims were successful out of 40 percent who collected the forms. But again, as a community, we also have elders who also prefer to use a non-violent method to resolve these problems. ${ }^{23}$

The medical practitioner also pointed out that:

I have a recent experience. A friend's daughter applied, I cannot remember if she actually wore a hijab or it was her name they saw, and they were going to block her from coming for the interview, even though when they did the screening test, she probably surpassed all of them. But the eagle eye of a brother who is working there spotted the girl and helped her so as to make sure her name was not removed from the list. At the end of the day, she is here now. Many things happen to Muslims here. Many would go unnoticed, and few like the one I mentioned may be discovered, and when we do, we are able to navigate our way around it. Like I said, every single person that belongs to a minority group that comes in is seen as a threat. I heard of a department wherein, when they were shortlisting, they made sure no Muslims were there. Unlike them, when I had to do similar shortlisting in this department, I did it in a very objective manner, in such a way that everybody is given equal opportunity. This is what Islam teaches. ${ }^{24}$

\section{Doubtful Competency}

Some respondents complained that the superior officers excessively supervise Muslims, and sometimes sideline FMMPs for promotion despite their in-depth knowledge and hard work. In response to this, a respondent expressed the following:

...when such a thing happens, for me, the simplest solution is for us to address two things: work hard, know your job well, and if it has to do with study, study well; let us be firm and not waiver. Then, we put our trust in Allah. ${ }^{25}$

\section{Unionism}

Unionism among the Christians is mostly divided across denominations and factions. For example, Christian denominations include Catholic, Pentecostal, The Redeemed Christian Church of God (RCCG), and Deeper Christian Life Ministry. The well-established Christian unions are seen as a source of power imbalance. According to a respondent: 
They use the strength in their numbers to prevent Muslims from holding important positions. ${ }^{26}$

On the other hand, a male medical practitioner focused on the potential advantage of Muslims being relatively united compared to the Christians:

... a Muslim community cannot be divided, and that is our strength and pride. The Christians can continue with their separation and ideologies. Muslims are the same everywhere, and division will not help us, and the fact that there is only one Mosque in UCH helps to strengthen our unity. ${ }^{27}$

\section{Conclusion}

Based on the observations made throughout the course of this study, there is strong evidence to conclude that FMMPs are being subjected to intimidation and oppression; and this in turn severely affects their working conditions and career paths. It is also concluded that the primary factor affecting the level of discrimination faced by FMMPs is their Islamic dress code, especially the hijab. The bias towards FMMPs is further amplified by the lack of Muslims occupying top posts in the management (only one Muslim is a deputy director). The study also discovered several challenges confronting FMMPs that are compounded by the inability of FMMPs to complain or report their cases to appropriate channels due to ingrained fear. This sentiment of fear among most FMMPs in $\mathrm{UCH}$ was felt throughout the course of this research. Only when FMMPs see and understand the need to stand up against discrimination will meaningful change occur.

\section{Recommendations}

From the findings, this study recommends the following:

- The government should uphold the principle of religious freedom and allow Muslims to practise their religion without harassment.

- The UCH management must ensure that the recruitment, employment, and promotion process is fair, just, and objective.

- Female Muslim medical practitioners should be free to practise their religion in an environment without spite, intimidation, and suspicion. 
- Management policies should be reviewed and new ones introduced to better accommodate issues such as the wearing of the hijab and prayer at work.

- There should be more advocacy and awareness of the challenges confronting FMMPs based on Article 18 of the Universal Declaration of Human Right and Section 38 (1) of the 1999 Nigerian constitution, which provides that: "Every person shall be entitled to freedom of thought, conscience, and religion, including freedom to change his religion or belief, and freedom (either alone or in community with others, and in public or in private) to manifest and propagate his religion or belief in worship, teaching, practice and observance".

\section{Notes}

* Muritala Kewuyemi Kareem, is a Senior Lecturer in the Department of Arabic and Islamic Studies, University of Ibadan, Ibadan, Nigeria. He is a chartered accountant. His teaching and research interests mainly concern Islamic Economic Systems, Islamic Banking and Finance, Islamic Law and Theology.

** Jamilah Adenike Adeogun, is a Graduate Student in the Department of Arabic and Islamic Studies, University of Ibadan, Ibadan.

1. An oral interview with Munibu/UCH/Ibadan/July 28, 2017.

2. An oral interview with Maahii/Lecturer/UCH/Ibadan/July 31, 2017.

3. An oral interview with Munibah/UCH/Ibadan/May 17, 2017.

4. An oral interview with Haatifah/UCH/Ibadan/April 25, 2017.

5. An oral interview with Haatif/UCH/Ibadan/July 31, 2017.

6. An oral interview with Munibu/UCH/Ibadan/July 28, 2017.

7. Surah al-Nur: 30

8. Surah al-Nur: 31

9. An oral interview with Baatini/UCH/Ibadan/July 31, 2017.

10. An oral interview with Aahir/UCH/Ibadan/July 31, 2017.

11. An oral interview with Maahii/UCH/Ibadan/July 28, 2017.

12. An oral interview with Aahir/UCH/Ibadan/July 31, 2017.

13. An oral interview with Zaahirah/UCH/Ibadan/May 22, 2017.

14. An oral interview with Aahir/UCH/Ibadan/August 8, 2017.

15. An oral interview with Aahirah/UCH/Ibadan/May 31, 2017.

16. Layla/UCH/Ibadan/May 30, 2017.

17. An oral interview with Maahiyah/UCH/Ibadan/May 30, 2017.

18. An oral interview with Munibah/UCH/Ibadan/June 4, 2017.

19. An oral interview with Najatu/UCH/Ibadan/August 8, 2017.

20. An oral interview with Haatifah/UCH/Ibadan/August 8, 2017.

21. An oral interview with Haatifah/UCH/Ibadan/April 18, 2017. 
22. An oral interview with Numaysah/UCH/Ibadan/May 10, 2017.

23. An oral interview with Aahir/UCH/Ibadan/July 28, 2017.

24. An oral interview with Aahir/UCH/Ibadan/August 8, 2017.

25. An oral interview with Munibu/UCH/Ibadan/August 8, 2017.

26. An oral interview with Layla/UCH/Ibadan/June 14, 2017.

27. An oral interview with Aahir/UCH/Ibadan/August 8, 2017.

\section{References}

1. Mary Bull, Medical Services in Nigeria 1954-1955 (Oxford: Oxford Development Project Report, 1995).

2. N.R.E. Fendall, 'A History of the Yaba School Medicine, Nigeria,' West African Medical Journal 16 (1967):118.

3. Muritala K. Kareem, 'Islamic Banking and the Question of Secularism in Nigeria,' Ilorin Journal of Religious Studies (IJOURELS) 6, no. 1 (2016): 7799.

4. Salim Al-Hassani, Women's Contribution to Classical Islamic Civilization: Science, Medicine, and Politics (n.p: Muslim Heritage, 2013).

5. B. Freyer Stowasser, Women in the Qur'an, Traditions and Interpretations (New York: Oxford University Press, 1994).

6. Sophia J. Ali, 'Challenges Facing Women Employees in Career Development: A Focus on Kapsabet Municipality, Kenya,' International Journal of Current Research 3, no. 8 (2011), 196-203.

7. Amina Wadud, Qur'an and Woman: Rereading the Scared Text from a Woman's Perspective (New York and Oxford: Oxford University Press, 1999), xii - xiii.

8. Amina Wadud, Inside the Gender Jihad: Women's Reform in Islam (Oxford: One World, 2006), 219-20.

9. Zakaria Yakubu, 'Entrepreneurs at Home: Secluded Muslim Women and Hidden Economic Activities in Northern Nigeria,' Nordic Journal of African Studies 10, no. 1 (2001): 107-23.

10. Fatima L. Adamu, 'Gender Myth about Secluded Women in Hausa Society of Nigeria' in Gender Perceptions and Development in Africa, ed. Mary E. Modupe Kolawole (Lagos: Arrabon Academic Publishers, 1998), 231.

11. Chris Allen, Arshad Isakjee and Ozlem Ogtem Young, Maybe We are Hated: The Experience and Impact of Anti-Muslim Hate on British Muslim Women (Birmingham: The University of Birmingham, 2013).

12. Abdulmumini A. Oba, 'The Hijab in Educational Institutions and Human Rights: Perspectives from Nigeria and Beyond,' Identity, Culture \& Politics: An Afro-Asian Dialogue 10, no. 1 (July 2009): 51-74.

13. Fatima Abubakre, 'Media Influences on the Perceptions of the Usage of Hijab in Nigeria's Public Institutions and Surrounding Controversy in the Lagos-Ibadan Axis,' Journal of Muslim Minority Affairs 38, no. 4 (2018).

14. Amani Hamdan, 'The Issue of Hijab in France: Reflections and Analysis,' Muslim World Journal of Human Rights 4, no. 2 (2007).

15. Doris Weichselbaumer, Discrimination against Female Migrants Wearing Headscarves, Discussion Paper no.10217 (Bonn: Institute of Labor Economics, 
2016).

16. Chouki El Hamel, 'Muslim Diaspora in Western Europe: The Islamic Headscarf (Hijab), the Media and Muslims' Integration in France,' Citizenship Studies 6, no. 3 (2002): 293-308.

17. Asifa Siraj, 'Meanings of Modesty and the Hijab Amongst Muslim Women in Glasgow, Scotland,' Gender, Place \& Culture 18, no. 6 (2011).

18. Rachel Anderson Droogsma, 'Redefining Hijab: American Muslim Women's Standpoints on Veiling,' Journal of Applied Communication Research 35, no. 3 (2007).

19. Dominic Abrams \& Michael A. Hogg, Social Identifications: A Social Psychology of Intergroup Relations and Group Processes (New York: Routledge, 1988).

20. Healey F. Joseph, Race, Ethnicity, Gender and Class, $4^{\text {th }}$ ed. (New York: Sage Publications, 2006).

21. Richard T. Schaeffer, Racial and Ethnic Groups, $10^{\text {th }}$ ed. (Upper Saddle River, New Jersey: Pearson, 2006). 